Abstracta Iranica Abstracta Iranica

Revue bibliographique pour le domaine irano-aryen

Volume 42-43 | 2021

Comptes rendus des publications de 2019-2020

\title{
Hamid Rezaei Yazdi, Arshavez Mozafari (eds.). Persian Literature and Modernity: Production and Reception
}

\section{Behnam Fomeshi}

\section{(2) OpenEdition \\ 1 Journals}

\section{Electronic version}

URL: https://journals.openedition.org/abstractairanica/54344

DOI: 10.4000/abstractairanica.54344

ISSN: 1961-960X

Publisher:

CNRS (UMR 7528 Mondes iraniens et indiens), Éditions de l'IFRI

\section{Electronic reference}

Behnam Fomeshi, "Hamid Rezaei Yazdi, Arshavez Mozafari (eds.). Persian Literature and Modernity: Production and Reception", Abstracta Iranica [Online], Volume 42-43 | 2021, document 1, Online since 30 December 2021, connection on 13 December 2022. URL: http://journals.openedition.org/ abstractairanica/54344 ; DOI: https://doi.org/10.4000/abstractairanica.54344

This text was automatically generated on 13 December 2022 .

All rights reserved 


\title{
Hamid Rezaei Yazdi, Arshavez Mozafari (eds.). Persian Literature and Modernity: Production and Reception
}

\author{
Behnam Fomeshi
}

\section{REFERENCES}

Hamid Rezaei Yazdi and Arshavez Mozafari (eds.). Persian Literature and Modernity:

Production and Reception. New York: Routledge, 2019, 256 p.

1 The volume considers the relation between modernity and tradition in Persian literature as one of continuity, rather than as a break. "Assuming the logic of alternative modernities, this volume prioritises the particularity of Iranian modernity" (4). "Covering literary experiments from the twelfth to the twentieth centuries" (i), it places "the introduction of European works" "alongside a whole series of other determinants that shaped the modern literary imaginary" (5). It consists of an introductory chapter, followed by seven chapters and an index.

2 The volume has two parts. Part One "explores key but repressed concepts of the literary tradition that assisted in the comprehension, sculpting and refashioning of modernity" (4). Focusing on munāzirah, Yazdi argues that "prevalent analytical paradigms such as translation, imitation and influence ... must be supplanted by one that heeds the parallel, and simultaneous, coexistence of Iranian and Islamic literary traditions alongside transnational trends - a synthesis that Jamālzādah epitomizes in his work" (25). Focusing on "demonic love", Mozafari studies Hidāyat's Parvin Dukhtar-i Sāsān and 'Alavì’s "Dīv! . . Dīv!", two works from interbellum Iran (1921-41), "a pivotal period in the development of a local discourse on willpower" (85). Bowles argues that "Europe's literary Modernity has non-European likenesses ... for themore elementary reason that Europeans are rather late entrants to the game" (113). This chapter moves from "discursive Modernity in philosophy and speculative theology" (114) of 
Suhrawardī and Mullā Șadrā's to the sabk-i hindī's Modernism in Șầib's poetry. Focusing on the "expression of discontent (nārizāyatī)", Montazeri shows how such a "recurring theme in the history of Persian poetry", "became recognised as a means of crystallising modern sociopolitical opposition" with the introduction of Shir $r$ i Naw (New Poetry) (141). She argues thatthe "spillages of predestination and freewill on both sides" of the tradition/modernity divide "undermines the dominant hermeneutic discourses" (153).

3 Part Twois "dedicated to a broader look at elided structural and processual aspects of modern Persian literature" (5). Through studying the figure of the prostitute in Iranian popular literature, Gahan problematizes "two grand assumptions" about modern Iranian literature; i.e. "modern literature emerged as a primarily political instrument" and the "Iranian novel, thematically and formalistically, is a mere imitation of Western novels" (165).Elaborating on Abū al-Qāsim Lāhūtī's literary activities in Istanbul and Moscow, Hodgkin argues that "Classical Persian models and forms ... would continue to provide building materials for Soviet Persian literary modernization, even as the admonitions of the bodies in the bricks became difficult to interpret in public, and perhaps even inscrutable"(201). Vaziri explores Taqvā'î's 1969 Bād-i Jin 's “aesthetic procedures for pursuing and producing what has been canonized as a modernist form the Iranian New Wave film - through a distinctly ethnographic gaze that refracts and abstracts historical information" (213). She positions this documentary "as an exemplary moment within a larger movement undergirding the co-constitution of Iranian literary and filmic modernity and the development of Iranian anthropology" (213). This volume will appeal to the scholars of Persian literature, more particularly those interested in the relation between modernity and Persian literature.

\section{AUTHORS}

\section{BEHNAM FOMESHI}

Monash University, Australie 